Научный труд Г.Г. Касарова является серьезным вкладом в исследование истории России. Он открывает большие возможности для новых исследований стачечного движения в России. Данная хроника является полноценной источниковой базой для исторической науки.

Учитывая уникальность данной монографии, есть все основания считать, что она будет в числе наиболее востребованных научных трудов по истории стачечного движения царской России.

$$
* * *
$$

1. Стачечное движение в России в годы Первой мировой войны. Июль 1914 г.- февраль 1917 г.: Хроника / Автор-составитель Г.Г. Касаров. - М.: Спб.: Нестор - история, 2019. - 832 с.

2. Г.Г. Касаров Партия социалистов-революционеров (конец ХІХ в. - февраль 1917 г.): элективный курс лекций. - М.: МАДИ, 1995. - 92 с.

3. Г.Г. Касаров Политический протест профсоюзов Москвы во время первой мировой войны (1914 - февраль 1917 г.) // Государство, общество, церковь в истории России XX-XXI веков. Материалы XVI Международной научной конференции: в 2 частях. - Иваново: ИГУ, 2017. - С. 271-277.

\title{
Кистанов С.В. \\ Распространение нелегальной антиправительственной литературы на территории Пензенской губернии в 1902 г.
}

ФГБОУ ВО Мордовский государственный университет им. Н.П. Огарёва

(Россия, Саранск)

doi: 10.18411/trnio-09-2021-36

\section{Аннотация}

В статье рассматривается распространение нелегальных печатных изданий партией социалистов-революционеров в Пензенской губернии в 1902 г. На этот период приходится начало массового распространения нелегальной печати в Среднем Поволжье. Отмечается реакция властей на эти события и их действия для пресечения антиправительственной деятельности.

Ключевые слова: губерния, политическая партия, социалисты-революционеры, агитация, листовки, полиция.

\section{Abstract}

The article deals with the distribution of illegal printed publications by the Party of Socialists-Revolutionaries in the Penza province in 1902. This period marks the beginning of the mass distribution of illegal printing in the Middle Volga region. The reaction of the authorities to these events and their actions to suppress anti-government activities are noted.

Keywords: province, political party, socialists-revolutionaries, agitation, leaflets, police.

Начало XX в. для Российской империи совпало с разворачиванием широкомасштабного социально-экономического и политического кризиса, отражением которого стали российские революции 1905-1907 и 1917 гг. Нежелание властей империи приводило к расширению поля деятельности для их политических противников, одними из выразителей которых являлись политические организации как либеральной, так и революционной направленности. Начало XX в. стало периодом формирования и начала практической деятельности таких революционных политических партий как социалдемократы (РСДРП) и социалисты-революционеры (ПСР, эсеры). Обе партии в начале процесса своего структурирования преимущественно использовали в качестве метода антиправительственной работы распространение нелегальной литературы (листовки, прокламации, брошюры).

Следует отметить, что данный период является наименее исследованным в деятельности революционных политических партий, особенно это касается региональной 
историографии. Большое внимание уделяется именно самим процессам формирования партийной структуры, создание местных групп политических партий, наконец, отмечаются крупные события в партийной истории. Но мелкая, практически ежедневная работа социалдемократов и социалистов-революционеров зачастую лишь упоминается вскользь, но подробно не рассматривается [4]. Поэтому исследование распространения нелегальной революционной печати на региональном уровне представляется актуальной и необходимой для создания объективной картины деятельности революционных организаций накануне первой российской революции.

Отметим, что распространение литературы представителями РСДРП на территории Среднего Поволжья в целом и Пензенской губернии в частности в первые годы XX в., было единичными случаями, что объяснялось, прежде всего, социальным составом региона с преимущественно крестьянским населением. В связи с этим, основную роль в распространении революционной литературы принадлежит партии эсеров, которая начала наращивать данный вид своей деятельности в 1900-1901 гг. [5]. Однако объемы распространяемой нелегальной литературы были не велики, что легко объясняется ее не местным происхождением. Листовки и прокламации прибывали из южных городов России (преимущественно из Одессы) и конфисковались, обычно, в единичных экземплярах. Все поменялось в 1902 г., когда местные эсеры завершили формирование местных губернских организаций, и при них стали организовываться собственные подпольные типографии.

Следует отметить, что департамент полиции и губернские жандармские управления начали активизацию борьбы с распространением нелегальной литературы уже с середины 1901 г. когда стали поступать сведения о росте ее числа среди учеников гимназий, училищ и семинарий, расположенных в Пензе, Саратове и Казани. Начальник пензенского ГЖУ в мае 1901 г. отчитался в департамент полиции о мерах по борьбе с появлением значительного количества прокламаций в губернии, среди которых предполагалось усилить полицейский надзор в местах наибольшего скопления народа и установить необходимый контроль за наиболее подозрительными лицами [2, л. 45].

Однако подобных мер было явно недостаточно, и поэтому в 1902 г. число эсеровских революционных изданий продолжало расти, при этом следует отметить, что значительно расширяется география подобных находок (большинство уездов губернии), а единичное распространение литературы меняется на массовое. Данные тенденции были обусловлены деятельностью в Пензе подпольной типографии партии эсеров, которая стремилась как можно шире охватить пропагандой население Пензенской губернии.

По числу случаев обнаружения нелегальной эсеровской литературы лидирует Пензенский уезд (и, прежде всего, сама Пенза), в котором было отмечено 26 случаев обнаружения эсеровских брошюр, листовок и прокламаций, значительно уступает ему Инсарский уезд - 9 случаев, в Саранском уезде отмечено 3 случая обнаружения эсеровской литературы, в Мокшанском и Наровчатском уездах - по два, в Городищенском и Чембарском по одному $[1 ; 3]$.

В Пензенском уезде находки эсеровской нелегальной литературы происходили на протяжении всего 1902 г., но своеобразный максимум случаев обнаружения пришелся на весну 1902 г. - 11 случаев (прежде всего, март и апрель) из 26, или 42,3 \% от общего числа случаев, что выпадает на период работы эсеровской подпольной типографии в губернском центре. Соответственно, на лето приходится лишь 2 случая обнаружения нелегальной литературы, что совпадает со временем разгрома эсеровской типографии, на осень (октябрьноябрь) - 6 случаев, на декабрь 1902 г. - 7, что, во многом, является отголоском работы эсеровской типографии [1].

Что же касается уездов губернии, то в них максимум случаев обнаружения эсеровской литературы приходится на лето 1902 г. -8 из 18, что составляет $44 \%$ от общего числа случаев обнаружения, что вполне логично объясняется временем доставки нелегальной литературы от места ее производства к местам распространения. На весну 1902 г. приходится 3 случая обнаружения, на осень - $6[1 ; 3]$. Лишь по случаю в Городищенском уезде, где были 
обнаружены присланные по почте 2 прокламации «В борьбе обретешь ты право свое», точных данных по времени их получения в архивном деле не сохранилось [1, л. 369].

Что же касается самой типографии социалистов-революционеров в Пензе, то к лету 1902 г. на ее след вышли жандармы и полиция. Ими было выявлено, что подпольная типография располагалась на конспиративной квартире, которую содержал присяжный поверенный Борис Тарасов, также был установлен круг лиц, причастных к распространению нелегальных эсеровских изданий. В ночь на 28 августа 1902 г. последовал вполне закономерный итог - типография была разгромлена полицией. При проведении обыска на квартире Тарасова были обнаружены около 15 пудов чистой газетной бумаги, около 5 пудов типографского шрифта, наполовину израсходованный бочонок типографской краски, а также усовершенствованный типографский станок с готовым набором брошюры «О податях и налогах», а также иные инструмент и принадлежности типографии. Кроме типографского оборудования и расходных материалов, полицией были обнаружены брошюры «О податях и налогах», «Правда о бедствиях простого народа», «Как могут крестьяне постоять за себя» и «Ко всему русскому люду». Было также отмечено, что на части прокламаций стояли поддельные штемпели жандармских управлений о том, что брошюры разрешены цензурой [2, л. 74-75].

Говоря о распространении эсеровской литературы в пределах Пензенской губернии, стоит отметить, что первые «находки» в Пензе состоялись 1 марта 1902 г., когда директор пензенской гимназии обнаружил у ворот своего учебного заведения 2 гектографированные прокламации. В тот же день 2 прокламации были обнаружены Мартыном Монаховым, а 5 прокламаций нашел пожарный Анисимов [1, л. 2, 5]. Следовательно, мы имеем массированное разбрасывание нелегальных прокламаций местными эсерами.

В Пензенском уезде первые прокламации в 1902 г. были найдены 9 марта у сына псаломщика Минева Пор-Архангельским волостным старшиной. В Чембарском уезде антиправительственные прокламации читались крестьянами села Свищево в марте 1902 г. В Инсарском уезде первые эсеровские брошюры были найдены и переданы властям земским начальником 5-го участка 10 июля. Среди обнаруженных были 5 гектографированных тетрадей «Хитрая механика», 3 - «Письмо ко всему русскому крестьянству», «Устав крестьянского союза - братства для защиты народных прав» и другие. Следовательно, и в этом случае эсеры провели массовую разброску своих нелегальных изданий. В Саранском уезде брошюру «Крестьянское дело» читали в селе Большой Вьясс в июле 1902 г. В Мокшанском уезде брошюра «Что делать?» 12 октября была получена землевладельцем в селе Михайловка [1, л. 10, 144, 202, 212, 235].

Что же касается самых массовых акций эсеров по распространению своих нелегальных печатных изданий, то следует отметить следующие эпизоды. В ночь на 1 мая ночные сторожа в Пензе обнаружили в районе 2-й и 3-й частей 108 экземпляров, как было указано, «преступных воззваний». В ночь на 29 октября в Пензе было разбросано преимущественно во дворах 113 экземпляров листовок под названием «Что делать?» (48 - в районе 1-й части, 34 - 2-й и 31 - 3-й). 19 декабря 19 экземпляров брошюры «Ко всему русскому крестьянству» были обнаружены на базаре Пензы. 17 апреля при обыске у ученика пензенской духовной семинарии Гумилевского были обнаружены 20 брошюр разных наименований и множество листовок [1, л. 41, 91, 112, 123]. Как мы видим из примеров и наиболее крупные «находки» полиции относятся к Пензе, в которой и действовала подпольная эсеровская типография.

Вне Пензы крупные находки изданий ПСР в 1902 г. были обнаружены лишь в селе Акшенас Инсарского уезда. В нем в период между 9 июня и 9 июля было обнаружено 33 экземпляра эсеровской печатной продукции, в том числе «Письма ко всему российскому крестьянству» (5 экземпляров), «Солдатская памятка» (3 экземпляра), «Беседы о земле» (3 экземпляра) и другие, всего 12 наименований [3, л. 3].

При этом необходимо отметить, что в 1902 г. практически отсутствуют упоминания о единичных находках нелегальной литературы. Пензенские эсеры, имея в своем 
распоряжении типографию, перешли от единичного к массовому распространению своей печатной продукции.

Таким образом, 1902 г. стал для эсеров Среднего Поволжья новой ступенью в их антиправительственной деятельности, так как в этот год началось расширение географии и масштабности их деятельности, главным методом которой, по-прежнему, являлось распространение нелегальной партийной литературы. 1902 год стал надежным фундаментом для дореволюционного пика распространения антиправительственной пропаганды, пришедшегося на 1903 год.

$$
* * *
$$

1. ГАПО. Ф. 5. Оп. 1. Д. 7339.

2. ГАРФ. Ф.102. Оп. 226. Д. 80. Литера Г.

3. ГАРФ. Ф.102. Оп. 230. Д. 360. Ч. 145.

4. История Мордовии: от эпохи великих реформ до великой российской революции / В.М. Арсентьев, Н.М. Арсентьев, С.Б. Бахмустов [и др.]; под ред. Н.М. Арсентьева, В.А. Юрченкова. - Саранск: изд-во МГУ им. Н.П. Огарева. 2005. 412 с.

5. Кистанов С.В. Распространение нелегальной литературы политическими организациями России на рубеже XIX - XX вв. (на материалах среднего Поволжья) // Тенденции развития науки и образования. 2020. № 64-3. C. 73-76. 